\title{
IDENTIFICATION AND PRIORITIZATION OF KEY STAKEHOLDER GROUPS IN MARKETING COMMUNICATION OF COLLEGES
}

\author{
Marie Slabá, Peter Štarchoň, Ivan Jáč
}

\section{Introduction}

A prerequisite for creation and implementation of communication strategy of any subject is a thorough market analysis. That is why this paper will also first briefly analyze the market of tertiary education in Slovakia and the Czech Republic. One of the main features of tertiary education is the growing competition on the side of offers and adverse tendencies on the side of demand caused by the demographic development. According to the prognosis of the Institute for Information in Education which came to be within the scope of the RELIK project (Reproduction of Human Capital) as well as demographic model of Czech Statistical Office, in 2050 there will be a decrease in the number of nineteen-year-olds (potential applicants for college studies) by more than 30 thousand compared to the current situation [7], [9]. There is a similar development according to analytical-prognostic study of the Institute of Information and Prognosis of Schools titled The development of indexes of Slovak tertiary educational system in years 1990-2005 and the prospect by the year 2020 expected in Slovakia [18]. For now this fact to a certain extent balances the "put-off, in the past unsatisfied demand for tertiary education among middle-aged high school graduates" [12, p. 43], which is also reflected in higher interest in combined or external and distant forms of studies, life-long education and university of the third age, as well as in the growing number of students in private colleges [12].

The second key aspect is a significant growth of competition due to the influence of private colleges as well as foreign institutions. Nowadays in the Czech Republic there are altogether 70 tertiary educational institutions. Out of that number 26 colleges have a status of public college, two of them are state universities and 44 are private colleges [14]. In Slovakia there are 20 public colleges, three state universities, 13 private colleges and four foreign colleges [11].

Another factor, which will influence the work of colleges and universities, is the change in the financing system. A drop in the provided financial resources is expected, ranging from 5 up to $20 \%$, depending on evaluation of the quality of tertiary education. The mentioned financial resources will be allocated according to the so called performance criteria which will encompass assessment of research, qualification structures as well as international cooperation. This measure is a reaction to the falling demographic curve, but also it is supposed to support the diversification of colleges and universities, which follows from the Higher Education White Paper [12]. In Slovakia in 2014 the complex accreditation of colleges and universities will start, whose results will also influence the financing of tertiary educational institutions.

Naturally there are further aspects and reasons of the growing importance of marketing communication in the circumstances of colleges related to individual groups of stakeholders, e.g. in the context of social responsibility [10], related to organizational structure [3], or from the view point of enhancing quality of the offered services in the sphere of higher education [21] or in the context of the possibilities of internationalization of provided education [15]. All these aspects aim at the necessity of implementation of a new approach also in the marketing communication of colleges related to 
its higher effectiveness not only in the field of attracting quality applicants, but also in the field of effective obtaining of financial resources and other accessible funds as well as growing goodwill and image of the tertiary school. One of the modern trends, which effectively aim marketing communication at different groups of target markets (not only students), is the Stakeholder Circle Methodology.

\section{Marketing Communication and Stakeholder Management}

If we want to elaborate the question of effective marketing communication, the first step is the choice of target group, at which marketing communication will be focused. Nowadays stakeholder management is considered a very important element of managerial practice, theory and strategy [4], which was chosen by authors as a modern approach for the sphere of their own research of marketing communication. From the view point of the modern approach of stakeholder management, the choice of target groups is a part of the so called stakeholder analysis [17], which creates one of the basic elements of stakeholder management [5]. Analysis and mapping of stakeholders is an important part of stakeholder management in the sphere of nonprofit organizations [2], among which can also be considered different colleges and universities. This fact has been confirmed by a glossary entry topic of accessible literature as well as personal enquiries of experts in marketing communication of university institutions [16]. Analysis of college and university institutions' stakeholders have not yet been given proper attention, there is only a few research papers by foreign authors. This was another main ground for implementation of such a research, whose chosen outcomes are analyzed in this research paper.

\subsection{Stakeholder Circle Methodology}

Stakeholder Circle Methodology seems most effective for the sphere of marketing communication and establishment of pertinent target segments because its proceeding can effectively be applied to commercial as well as noncommercial organizations. The hypothesis, which postulates the applicability of implementing Stakeholder Circle Methodology in marketing communication is verified by contemporary authors who are dedicated to the sphere of stakeholder management, e.g. Chinyio says that „Stakeholder Circle Methodology offers a device for project team (management), which is applied to identification and setting priorities of key stakeholders of a project (company activities), this device is further applied to creating an appropriate strategy and communication plan aimed at target stakeholders to assure the understanding of all needs and expectations of key stakeholders. The result of each step of Stakeholder Circle Methodology brings forward information necessary for projecting effectively targeted communication" [8, p. 103].

Stakeholder Circle Methodology itself consists of five basic steps: 1) identification of all relevant stakeholders, 2) prioritizing key stakeholders, 3) visualization of fey stakeholders, 4) creating a strategy of engaging stakeholders and effective communication, 5) monitoring effective communication with individual stakeholders [1], [20].

The primary goal of the first step of Stakeholder Circle Methodology lies in identification of all relevant stakeholder groups. The result of this step is a list of stakeholders which is a base for categorization of stakeholders and it tests the question - which stakeholders (individuals and/or groups) are influenced by the company activities or which stakeholders can influence the organization or its activities [1]. Second step of the Stakeholder Circle Methodology is setting own priorities among individual stakeholder groups. Stakeholder Circle Methodology makes it possible to assess the importance of stakeholders through four elementary factors force of influence of a stakeholder, engagement of a stakeholder in the company activities, the share of a stakeholder and his/her activity. Then it is necessary to choose from all relevant identified groups of stakeholders from the first step those groups, which are key for the given organization. Based on these factors the so called Stakeholder index is counted. In the third step visualization is accomplished which is a graphic presentation of the stakeholder structure through multidimensional maps. The fourth step deals with projecting a concrete strategy of stakeholder engagement in scope of the given project or activity and a creation of a plan of targeted marketing communication, where attention is given to the most relevant (i.e. key) stakeholders who have been specified during setting priorities of stakeholders in step 2 . 
The stakeholder value and their expectations (information about what the project demands from stakeholders and what stakeholders expect from the project) are the most essential information for creating targeted communication strategy. Consideration of this information about the value and expectations of stakeholders together with information on the level of support given to project by stakeholders and the interest of stakeholders in the project is essential for a successful projection of communication strategy. The final step of Stakeholder Circle Methodology aims at monitoring and verification of all communication efforts and effectiveness of communication strategy and marketing communication plan [8].

\section{Methodology of the Carried Out Research}

It is vital for successful establishment of effective marketing communication to firstly identify the key stakeholder groups at which a college or university should aim its communication. The most relevant method for identification of these groups was chosen the above described Stakeholder Circle Methodology.

Initial identification of relevant stakeholder groups of colleges was done through a glossary entry topic of foreign specialized literature, research reports as well as scientific papers. The basic chosen stakeholder groups were further adapted to the circumstances of Czech and Slovak market of tertiary education. Among the basic groups of stakeholders were included especially contemporary and potential students and the families of students, graduates, individual departments in colleges, marketing and PR departments, competition, resort organizations (e.g. Accreditation Committee), the public and many more.

The chosen method of marketing research was a questionnaire. Questionnaires were distributed via Internet using electronic enquiry through the so called CAWI method (Computer Assisted Web Interviewing). To set the target group of respondents the technique of quota and intentional selection was used. For this problem the technique of intentional selection of the sample is more acceptable than statistical representative techniques. Altogether 41 colleges and universities in the Czech and Slovak Republics were enquired. The rate of return was $60.98 \%$.
Two hypotheses were stated for the research. The first one follows from the premise that the priorities set for individual groups of stakeholders by respondents based on their professional judgment are different from priorities set based on the counted Stakeholder index. Second hypothesis follows from the assumption that the higher the Stakeholder index, the higher the priority of the given group of stakeholders (note: 1 is the highest priority, 15 the lowest priority).

Apart from own elaboration by the Stakeholder Circle Methodology, the received data were first processed with classical mathematical-statistical methods of data evaluation especially through calculating the median, weighted average and multiplicity. To verify the second hypothesis regression analysis and calculation of coefficient of correlation was used (for calculation of coefficient of correlation for linear regression function see Formula 1 from [6, p. 206]).

$$
r_{y x}=\frac{s_{x y}}{\sqrt{s_{x}^{2} s_{y}^{2}}}
$$

The main research problems analyzed in detail in this paper are a) identification of key groups of stakeholders and b) setting priorities of key stakeholder groups.

Identification and prioritization of key stakeholder groups is carried out based on the first two steps of Stakeholder Circle Methodology. Setting priorities of key stakeholder groups is carried out on two levels, namely first based on own professional judgment of respondents and after that based on the calculated Stakeholder index in the second step of Stakeholder Circle Methodology.

Identification of stakeholders calls for the following information: 1) the direction of stakeholder's influence (division of stakeholders into external and internal groups and setting the direction of influence on marketing communication - upwards, outwards, sidewards, downwards), 2) the significance of a stakeholder for the project - how the stakeholder contributes into the project, whether he/she influences it, 3) the significance of stakeholder for the project - if the stakeholder disposes of power to influence other stakeholders, offers necessary resources for marketing communication, etc., 4) stakeholder's demands on the project. 
To set priorities the following values are of key importance: the power of stakeholder's influence, stakeholder's engagement in the project, stakeholder's share and activity of stakeholder.

The power of stakeholder's influence and his/her engagement are evaluated on a scale from 1 to 4 . The value of share and activity of a stakeholder then can have a value from 1 to 5. Each value has its own qualitative statement but basically in both cases the value 1 means the lowest value and 4 or 5 means the highest value.

Another value is Urgency, the value of which is calculated based on the stakeholder share and his/her activities within marketing communication using an Urgency matrix into which values of combinations of the stakeholder's share value in marketing communication and his/her activities are inserted (Formula 2). The resulting value of Urgency indicates the necessity of activities within marketing communication aimed at given stakeholder group. Thus Urgency values express how urgent the activities of marketing communication of colleges are with respect to individual stakeholder groups. Both inputs take their values from 1 to 5 that is why Urgency also has these values.

Urgency $=I N T(\sqrt{\text { Stakeholder Value } * \text { Stakeholder Action } / 25} * 5)$

Caption:

INT

Stakeholder Value

Stakeholder Action

integer

stakeholder's share stakeholder's activity

Source: Software Stakeholder Circle

Based on the value of stakeholder's influence power, stakeholder's engagement in a project, stakeholder's share, stakeholder's activity - thus the calculated value of Urgency, the Stakeholder Index is set, which is calculated according to formula - see Formula 3: Stakeholder index.

Stakeholder index $=\left(\sum\right.$ Power, Proximity, Urgency $)$

Caption:

Power

Proximity

Urgency stakeholder's influence power stakeholder's engagement stakeholder's urgency for the project Source: Software Stakeholder Circle
The above mentioned hypotheses which will be verified based on analyses and research results are also linked with the second research problem - setting priorities of key stakeholder groups.

\section{Selected Outcomes of the Implemented Research}

This paper analyzes in detail the first two steps of Stakeholder Circle Methodology - namely identification and prioritization of stakeholders. From the point of view of prioritization it is interesting to compare the subjective priorities which have been allocated based on professional judgment of the questioned and objective priorities which have been set according to Stakeholder index. The interdependence of these priorities will be examined through regression analysis.

\subsection{Identification of Key Stakeholder Groups}

The following key stakeholder groups were identified through the implemented research: graduates, Accreditation Committee, Ministry of Education, youth and Physical Education, or in Slovakia Ministry of Education, Science, Research and Sport of the Slovak Republic (further MŠ), grant organizations and other resource providers, individual departments, faculties and their employees, competition, marketing and PR departments, media, teachers and officers for studies in secondary technical schools (further SOŠ) and higher vocational schools (further VOŠ), potential students, parents of students, current students, SOŠ, VOŠ, public, local community and common interest associations and employers.

It is vital to specify the following parameters for a detailed identification of individual groups of stakeholders: significance and importance of a stakeholder for marketing communication of a college and stakeholder's requirements for marketing communication of a college. Based on the research among the most commonly stated requirements ( $80 \%$ of cases) is information. Own reputation is demanded by graduates of colleges, meeting the demands of customers is required by internal groups of respondents among which belong the individual departments, faculties, marketing and PR departments. Most stakeholder groups contribute to marketing communication or they influence it (identically 
$40 \%$ of stakeholder groups), possibly have the necessary knowledge for marketing communication of colleges.

Further for each stakeholder the so called direction of influence is set and every stakeholder is moved among internal groups of stakeholders or external stakeholder groups. These parameters were not monitored in the research, since they are attributes of methodology which can be clearly assigned to any stakeholder group. The direction of influence has four forms:

- upwards - managers or control groups, in the case of a college for example the management of a college or marketing managers and all workers in marketing and PR departments;

- outwards - these are stakeholder groups which are not included in the project, such as e.g. suppliers, state administration bodies and autonomies, public and local community, common interest associations, customers - namely students - potential, current and future;

- sidewards - this group comprises especially of competition - other colleges and universities;
- downwards - team members, employees and individual departments and faculties.

According to the implemented research it is clear that most key groups of stakeholders are external groups with the direction of influence outwards. This direction of influence includes stakeholders who are not directly engaged in marketing communication of a college, while these are especially Accreditation Committee, MŠ, grant organizations and other resource providers, graduates and their parents, as well as employers of graduates. Internal stakeholders with this direction of influence are current students.

\subsection{Prioritization of Key Stakeholder Groups}

As mentioned above, prioritization is carried out based on a calculation of the so called Stakeholder index (Formula 3). To calculate the Stakeholder index, it is necessary to determine the value of all four basic values, which are the power of influence, engagement, share and activity of a stakeholder. These values are listed collectively for all groups of stakeholders in Table 1.

Tab. 1: The value of influence power, engagement, share and activity of stakeholders

\begin{tabular}{|c|c|c|c|c|c|}
\hline Stakeholder group & $\begin{array}{c}\text { influence } \\
\text { power }\end{array}$ & engagement & share & activity & urgency \\
\hline Graduates & 4 & 2 & 3 & 4 & 3 \\
\hline Accreditation Committee, MŠ & 3 & 1 & 3 & 3 & 3 \\
\hline $\begin{array}{l}\text { Grant organizations and other resource } \\
\text { providers }\end{array}$ & 2 & 1 & 2 & 2 & 2 \\
\hline $\begin{array}{l}\text { Individual departments, faculties and their } \\
\text { employees }\end{array}$ & 4 & 4 & 5 & 5 & 5 \\
\hline Competition, other colleges & 2 & 1 & 1 & 2 & 1 \\
\hline Marketing and public relations departments & 2 & 4 & 5 & 5 & 4 \\
\hline Media & 4 & 3 & 4 & 4 & 4 \\
\hline $\begin{array}{l}\text { Teachers and officers for studies of SOŠ, } \\
\text { VOŠ }\end{array}$ & 2 & 2 & 3 & 3 & 3 \\
\hline Potential students & 4 & 2 & 4 & 4 & 4 \\
\hline Parents of students & 2 & 1 & 3 & 3 & 3 \\
\hline Current students & 3 & 3 & 4 & 4 & 4 \\
\hline SOŠ, VOŠ & 2 & 2 & 2 & 2 & 2 \\
\hline $\begin{array}{l}\text { Public, local community, common interest } \\
\text { associations }\end{array}$ & 2 & 1 & 3 & 2 & 2 \\
\hline Employers & 1 & 2 & 1 & 2 & 1 \\
\hline
\end{tabular}


From the stated results follows that in the case of colleges the groups of stakeholders with the greatest level of influence are graduates, individual departments, faculties and their employers, media and potential students. Employers have the lowest power of influence. From the point of view of stakeholder engagement, the groups which are directly involved in marketing communication of a college comprise of individual departments, faculties and their employees and marketing and PR departments. Groups which are not directly at all involved in marketing communication are the Accreditation Committee, MŠ, grant associations and other resource providers, competition, parents of students, public, local community and common interest associations. Minimal (to zero) share in marketing communication have competitors and employers. On the contrary especially marketing and PR departments and individual departments, faculties and their employees have a great share in the success as well as failure of marketing communication. According to the results of primary research the most active stakeholder groups are individual departments, faculties and their employees and - naturally - marketing and PR departments of tertiary educational institutions.

Groups of stakeholders included from the point of urgency or necessity to start marketing activities towards the given stakeholder group comprise of individual departments, faculties and their employees. From the point of view of urgency, this group received the highest value 5, which expresses the inevitability of immediate activity. Even though these stakeholder groups play an important role in marketing communication of tertiary educational institutions, they are only paid a small attention that is why they receive the greatest value of urgency. Other stakeholder groups which require the greatest urgency of activities comprise of marketing and PR departments, media, potential and current students. In the short term it is necessary to plan marketing activities for groups of stakeholders whose calculated value of urgency was 3 . These are graduates, Accreditation Committee, MŠ, parents and teachers and officers for studies of SOŠ and VOŠ. There is only a small necessity of planning activities in marketing communication of the chosen colleges for groups identified as employers and competition (other colleges). In the medium term it is necessary to plan ordinary activities of marketing communication for grant organizations and other resource providers, SOŠ, VOŠ and the public, local community and common interest associations.

Calculated groups of Stakeholder index and allocated priorities based on Stakeholder Circle Methodology, as well as priorities stated based on professional judgment of the respondents are included in the following Table 2.

The highest value of the Stakeholder index was set for individual departments, faculties and their employees. The second group with the highest Stakeholder index is media which have the greatest ability to influence other stakeholder groups and are an important group of stakeholders to support a positive image and PR of a college and can also have an important impact on spreading positive WOM about a college. Another important stakeholder group which has the third highest Stakeholder index is the group of potential students who are closely followed by current students. Employers have the lowest value of Stakeholder index.

Based on results that are shown in Table 2: Stakeholder index and prioritization of stakeholder groups can be confirmed for the stated hypothesis which claims that priorities assigned by respondents for individual groups of stakeholders based on their professional judgment, differ from priorities which are assigned based on the calculated Stakeholder index. It is clear from the table that these priorities are different in almost all cases. Based on the Stakeholder index calculated from values of the power of influence of a stakeholder, engagement of a stakeholder which was set by respondents and the calculated value of urgency, priority 1 was given to individual departments, faculties and their employees. Even though these groups are very important, respondents themselves set for them priority 10. Marketing and PR departments, which also belong among internal stakeholder groups, were given priority 7 and based on Stakeholder Circle Methodology it was 5 . On the contrary, respondents themselves clearly gave priority 1 to potential applicants, according to rules of Stakeholder Circle Methodology potential students were given priority 3. Current students were given priority 3 by respondents. Based on Stakeholder Circle Methodology they were given priority only by one level different, namely priority number 4. From the point of view of marketing 
Tab. 2: Stakeholder index and prioritization of stakeholder groups

\begin{tabular}{|c|c|c|c|}
\hline Group of stakeholders & $\begin{array}{c}\text { Stakeholder } \\
\text { index }\end{array}$ & \begin{tabular}{|c|} 
Priority set \\
according to \\
Stakeholder Circle \\
Methodology
\end{tabular} & $\begin{array}{c}\text { Priority set } \\
\text { by } \\
\text { respondents }\end{array}$ \\
\hline Individual departments, faculties and their employees & 65.55 & 1 & 10 \\
\hline Media & 55.66 & 2 & 5 \\
\hline Potential students & 51.27 & 3 & 1 \\
\hline Current students & 50.53 & 4 & 3 \\
\hline Marketing and public relations departments & 49.79 & 5 & 7 \\
\hline Graduates & 45.78 & 6 & 4 \\
\hline Accreditation Committee, MŠ & 41.39 & 7 & 11 \\
\hline Teachers and officers for studies of SOŠ, vOŠ & 35.52 & 8 & 6 \\
\hline Parents of students & 31.13 & 9 & 2 \\
\hline SOŠ, VOŠ & 30.03 & 10 & 8 \\
\hline Grant organizations and other resource providers & 25.64 & 11 & 13 \\
\hline Public, Local community, common interest associations & 25.64 & 12 & 12 \\
\hline Competition, other colleges & 20.15 & 13 & 9 \\
\hline Employers & 19.40 & 14 & 14 \\
\hline
\end{tabular}

communication of a college, current students are those who spread the goodwill of a college, that is why there should be "investments" made to support the spreading of positive WOM by this stakeholder group. Current students also have a significant power to influence other groups - especially potential applicants. It is also necessary to be aware of the fact that current students as well as graduates, who were given priority 6 by the Stakeholder Circle software (respondents even consider this group of stakeholders the fourth most significant group), can spread the goodwill and positive WOM, however they can also bear the negative WOM. The biggest deviation of the priority set by respondents and set by software was shown related to the groups of students' parents. Only two groups of stakeholders (public, local community, common interest associations and employers) were given the same value by respondents as well as according to the rules of Stakeholder Circle Methodology.

The interdependence of Stakeholder index and priority set according to Stakeholder Circle Methodology was verified using regression analysis and calculation of correlation coefficient (line linear regression model - Formula 4). In this case the best seems linear regression model $E Y=\beta_{0}+\beta_{1}{ }^{*} x$, the estimate of the function is as follows:

Priority set according to $M S C=18.932-$

$$
-0.292 \text { * Stakeholder index }
$$

Explanations:

MSC

Stakeholder Circle Methodology

Source: Software Stakeholder Circle

Based on this model the null hypothesis $\mathrm{HO}: \beta_{1}=0$ was tested against hypothesis $\mathrm{H} 1$ : $\beta_{1}<0$. Since the result $\mathrm{P}$-value matching t-test was smaller than 0.001 , it is confirmed that the slope of the line $\beta_{1}$ is negative, thus it was statistically verified that the higher the calculated Stakeholder index for individual stakeholder groups, the higher the priority (and lower value of datum) of these stakeholders. This assertion can also be supported by the amount and sign of the calculated correlation coefficient $r=-0.990$ (coefficient of determination $R^{2}=97.9 \%$ ). Based on the carried out regression analysis the second hypothesis was verified that there is interdependence between Stakeholder index and the priority assigned according to Stakeholder Circle Methodology. 


\section{Conclusions}

On the basis of the carried out research the following key groups of stakeholders were determined: graduates, Accreditation Committee, MŠ, grant organizations and other resource providers, individual departments, faculties and their employees, competition (other colleges), marketing and public relations departments, media, teachers and officers for studies in SOŠ, VOŠ, potential students, parents of students, current students, SOŠ, VOŠ, public, local community, common interest associations and employers. Among the five most important stakeholder target groups of marketing communication were included individual departments, faculties and their employees, media, potential and current students and marketing and public relations departments.

Based on Stakeholder index from the point of view of marketing communication needs priority one was assigned to individual departments, faculties and their employees. Own employees and individual departments or faculties directly and indirectly take part in creating marketing communication strategy of the whole tertiary educational institution. In spite of the fact that these groups are very important, respondents themselves assigned to them value 10 , which means that these groups are not given enough attention within marketing communication of colleges. Priorities assigned to these groups evidently confirm their high importance for marketing communication of a college. Subjective perception of priority of these internal stakeholder groups is much lower than their priority given by Stakeholder Circle Methodology. This fact indicates that it is essential to support inner communication of colleges. Internal communication is a key part of modern holistic marketing, which includes apart from internal communication also other three key pillars - integrated marketing (or communication), which contributes to reaching synergy effect, socially responsible marketing and relational marketing, which aims not only at customers and key partners, but also all other stakeholders, including internal groups. If a college wants to be successful nowadays, it has to master all pillars of holistic marketing, including those linked to internal communication.

Second most important group from the point of view of marketing communication according to Stakeholder Circle Methodology was media. Respondents gave this stakeholder group priority five. From the point of view of marketing communication media are no doubt one of the key stakeholder groups of every organization since they have a great influence on all other stakeholder groups. Generally media are able to influence the public opinion. Since image and goodwill is very important for colleges and universities, they play an important role in their marketing communication. Naturally, key stakeholder groups comprise of potential as well as current students, whose needs are satisfied through main activities of tertiary educational institutions.

Both set hypothesis were verified based on carried out analyses. Thus we can state that priorities which are assigned based on professional judgment of respondents differ from priorities which were assigned to individual stakeholder groups based on the counted Stakeholder index. It can also be stated that the higher the value of Stakeholder index the higher the priority of the given stakeholder group for the needs of marketing communication.

\section{References}

[1] BOURNE, L. SRMM® Stakeholder Relationship Management Maturity [online]. Presented at 19-21 May 2008. St. Julians, Malta. Dr. Lynda M. Bourne, DPM, PMP, CMACS. Director, Stakeholder Management Pty Ltd. [cit. 2010-04-12]. Available from: http://www.stakeholdermapping. com/PDFs/SRMM_Paper.pdf.

[2] BRYSON, J.M. What to do when Stakeholders Matter? Stakeholder Identification and Analysis Techniques. Public Management Review. 2004, Vol. 6, Iss. 1, pp. 21-53. ISSN 1471-9037.

[3] EGER, L. Application of the corporate culture in the field of school management. $E+M$ Ekonomie a Management. 2010, Vol. 13, Iss. 3, pp. 26-32. ISSN 1212-3609.

[4] FASSIN, Y. The Stakeholder Model Refined. Journal of Business Ethics. 2009, Vol. 84, Iss. 1, pp. 113-135. ISSN 0167-4544.

[5] FREEMAN, R.E. Strategic Management: A Stakeholder Approach. Cambridge: Cambridge University Press, 2010. ISBN 978-0521151740.

[6] HINDLS, R., et al. Statistika pro ekonomy. Praha: Professional Publishing, 2006. ISBN 80-86946-16-9.

[7] HULíK, V. Prognóza počtu žáků a studentů v ČR do roku 2050 -výsledky a možnosti [online]. 
Praha: VŠE, Ústav pro informace ve vzdělávání [cit. 2010-02-05]. Available from: http://kdem. borec.cz/P_PDF/Hulik.pdf.

[8] CHINYIO, E., et al. Construction Stakeholder Management. Chicheser: Blackwell Publishing, 2010. ISBN 978-1-4051-8098-6.

[9] LANGHAMROVÁ, J., et al. Prognóza lidského kapitálu obyvatelstva České republiky do roku 2050 [online]. Praha: Vysoká škola ekonomická v Praze, Katedra demografie, Ústav pro informace ve vzdělávání [cit. 2010-02-07]. Available from: http:// kdem.vse.cz/resources/relik09/RELIK_2009.pdf.

[10] MARTINČÍK, D., POLÍVKA, M. Contribution of corporate social responsibility to the shareholder value: experimental perspective. E+M Ekonomie a Management. 2012, Vol. 15, Iss. 3, pp. 108-124. ISSN 1212-3609.

[11] Ministerstvo školstva, vedy, výskumu a športu Slovenskej republiky. Vysoké školy $v S R$ [online]. [cit. 2013-04-23]. Available from: http://www. minedu.sk/vysoke-skoly-v-sr/.

[12] Ministerstvo školství, mládeže a tělovýchovy. Bílá kniha terciárního vzdělávání. Praha: Ministerstvo školství, mládeže a tělovýchovy, 2009. ISBN 978-80-254-4519-8.

[13] Ministerstvo školství, mládeže a tělovýchovy. Statistická ročenka školství 2012/2013 - výkonové ukazatele [online]. Praha: MŠMT, 2013 [cit. 2013-04-20]. Available from: http://toiler.uiv.cz/ rocenka/rocenka.asp.

[14] Ministerstvo školství, mládeže a tělovýchovy. Přehled vysokých škol [online]. Praha: MŠMT, 2013 [cit. 2013-04-23]. Available from: http://www. msmt.cz/vzdelavani/prehled-vysokych-skol.

[15] SAEE, J. Internalisation strategy for education in the 21st century. Journal of Business Economics and Management. 2004, Vol. 5, Iss. 2, pp. 77-84. ISSN 1611-1699.

[16] SLABÁ, M., HESKOVÁ, M. Marketing vysokoškolských institucí. Marketing Science \& Inspirations. 2012, Vol. 7, Iss. 1, pp. 15-24. ISSN 1338-7944.

[17] SUSNIENE, D., PURVINIS, O. Empirical insights on understanding stakeholder influence.
Journal of Business Economics and Management [online]. 2013, iFirst: 1-15 [cit. 2013-11-06]. Available from: http://www.tandfonline.com/doi/ abs/10.3846/16111699.2013.785974.

[18] Ústav informácií a prognóz školstva. Vývoj ukazovatelov vysokého školstva [online]. Bratislava: Ústav informácií a prognóz školstva, 2013 [cit. 2013-02-23]. Available from: http://www.uips.sk/ vysoke-skolstvo/vyvoj-ukazovatelov-vysokehoskolstva.

[19] Ústav pro informace ve vzdělávání. Vývoj terciárního vzdělávání [online]. Praha: Ústav pro informace ve vzdělávání, 2011 [cit. 2011-09-13]. Available from: http://www.uiv.cz/clanek/733/2168. [20] WALKER, D.H.T., BOURNE, L., ROWLINSON, S. Stakeholders and the supply chain. Procurement Systems: A Cross-industry Project Management Perspective. London: Taylor \& Francis, 2008. ISBN 0415416051.

[21] ZAFIROPOULOS, C., VRANA, V. Service quality assessment in a Greek higher education institution. Journal of Business Economics and Management. 2008, Vol. 9, Iss. 1, pp. 33-45. ISSN 1611-1699.

Ing. Marie Slabá, Ph.D. Institute of Technology and Business in České Budějovice

Department of Economics and Management slaba-ma@seznam.cz

doc. Mgr. Peter Štarchoň, PhD. Comenius University in Bratislava Faculty of Management Department of Marketing peter.starchon@fm.uniba.sk

prof. Ing. Ivan Jáč, CSc. Technical University of Liberec Faculty of Economics Department of Business Administration and Management ivan.jac@tul.cz 


\section{Abstract}

\section{IDENTIFICATION AND PRIORITIZATION OF KEY STAKEHOLDER GROUPS IN MARKETING COMMUNICATION OF COLLEGES \\ Marie Slabá, Peter Štarchoň, Ivan Jáč}

This paper shows the possibility of using the Stakeholder Circle Methodology for the identification and prioritization of key stakeholder groups for the purpose of marketing communication in colleges. At the beginning, we emphasize the necessity of the use of marketing communications in the context of the changing market situation of tertiary education in the Czech and Slovak Republics, then we present basic steps of the Stakeholder Circle Methodology and methodology of the research. The selected research results are compared and subjective priorities are assigned based on professional judgment and, at the end, objective priorities are identified by Stakeholder index and subsequently key stakeholder groups are identified. Particular individual departments, faculty and staff, the media, potential and present students, and marketing and public relations departments belong among the most important target groups of stakeholders in marketing communication of universities. Based on the research results, the importance of internal communication has to be supported by universities' marketing communication, followed by media relations forward to increasing a positive image and goodwill.

Key Words: Stakeholder, stakeholder circle methodology, stakeholder index, stakeholder identification, stakeholder prioritization.

JEL Classification: M31, M39.

DOI: 10.15240/tul/001/2014-4-008 